\title{
Strategic Priorities in Development of the Agro-Industrial Complex of the Krasnodar Region
}

\author{
M.A. Nesterenko \\ O.N. Saliy \\ I.N. Putilina \\ A.V. Berezhnoi \\ D.V. Rylov \\ Kuban state agricultural university, Russian Federation, Krasnodar, Kalinina St.13 \\ Email: nesterenko09@inbox.ru
}

\section{Doi:10.5901/mjss.2015.v6n5s3p176}

\section{Abstract}

The paper gives the agro-industrial complex characteristic of the Krasnodar Krai, analyzes the condition of its branches and defines key problems. It emphasizes such strategic development priorities of the agro-industrial complex of the Krasnodar Krai as the reclamation of land, development of the elite seed industry, intensive development of the animal industry, support of the small forms of economic management. The paper also considers the possibilities of the state support for regional agroproducers taking into account the entry of the Russian Federation in the ranks of the World Trade Organization. In compliance with that the paper offers the measures of the state regulation that is aimed to stimulation of key directions of the agrarian industry development of the region where the matter concerns a creation of the logistic basis and formation of the rural cooperation. As an example a model of the contract relations system concerning production, processing and sales of the pigbreeding products between the agricultural organizations, farm enterprises and farms of the population which can be used during the organization of productive processes both in other subsectors of the animal industry and in the branch of the plant industry. There is a conclusion that now a concentration of the state regulation on the oblique support measures for strategic development directions that is capable to provide a stimulation of "independent mechanisms" of the inner potential of the agroindustrial complex of the Krasnodar Krai.

Keywords: agro-industrial complex, Krasnodar Krai, state regulation, World Trade Organization, cooperation.

\section{Introduction}

\subsection{The agricultural organizations of Krasnodar Krai}

The agro-industrial complex (AIC) of the Krasnodar Krai unites all branches of the national economy on agricultural production, its processing and finishing to the consumer, and also on supply of machines and equipment.

The Krasnodar Krai is the region which has considerable advantages and opportunities, however, in the agrarian sector of the region is observed a number of negative tendencies.

So the main unit of the AIC of the Krasnodar Krai is the agriculture where the farms of all categories presented by various organizational and legal forms (table 1 ) are occupied.

From 2009 to 2013 the number of agricultural organizations has fallen by 87 units of all organizational and legal forms, except the limited liability companies (Selskoe khozyajstvo Krasnodarskogo kraya: statisticheskiy sbornik 2013, 2014). In our opinion, the main reasons of the reduction are the high risks in the agriculture and the insufficient rates of the agro-industrial market modernization. 
Table 1 - Organizational and legal forms of the organizations on agricultural production in the Krasnodar Krai

\begin{tabular}{|l|c|c|c|c|c|c|}
\hline Показатель & $2009 \mathrm{y}$. & $2010 \mathrm{y}$. & $2011 \mathrm{y}$. & $2012 \mathrm{y}$. & $2013 \mathrm{y}$. & from 2013. T0 2009 y., \% \\
Organizations on agricultural production, total & 3408 & 3438 & 3416 & 3402 & 3321 & 97,4 \\
including & 3 & 1 & 1 & - & - & - \\
Collective farms & 50 & 50 & 47 & 46 & 42 & 84,0 \\
Public industries & 151 & 140 & 138 & 130 & 130 & 86,1 \\
Public limited company & 44 & 43 & 37 & 33 & 26 & 59,1 \\
No-limited company & 206 & 192 & 184 & 181 & 170 & 82,5 \\
Private limited company & 2714 & 2781 & 2799 & 2823 & 2787 & 102,7 \\
Limited companies & 214 & 208 & 194 & 177 & 153 & 71,5 \\
Producers' and farmers' cooperative & 26 & 23 & 16 & 12 & 13 & 50,0 \\
\hline Other organizations & &
\end{tabular}

Except the agricultural organizations, the agricultural production is made by farms of the population, farm enterprises and individual entrepreneurs (table 2).

During the quantitative reduction of agricultural organizations, their share in the agricultural production increased from $58 \%$ in 2009 to $61 \%$ in 2013 , at the corresponding reduction of a share of farms of the population from $30 \%$ to $24 \%$, FE and individual entrepreneurs have increased the share of production from $12 \%$ to $15 \%$ (Selskoe khozyajstvo Krasnodarskogo kraya: statisticheskiy sbornik 2013, 2014).

Table 2 - The structure of the agricultural production of the Krasnodar Krai on categories of the farms, \%

\begin{tabular}{|l|c|c|c|c|c|}
\hline Indicator & $2009 \mathrm{y}$. & $2010 \mathrm{y}$. & $2011 \mathrm{y}$. & $2012 \mathrm{y}$. & $2013 \mathrm{y}$. \\
Farms of all categories & 100 & 100 & 100 & 100 & 100 \\
Agricultural organizations & 58 & 59 & 59 & 58 & 61 \\
Farms of the population & 30 & 29 & 27 & 27 & 24 \\
Farm enterprises and individual entrepreneurs & 12 & 12 & 14 & 15 & 15 \\
\hline
\end{tabular}

The total agricultural production in 2013 is 255 bil. rub. that is $45,4 \%$ more than the level of 2009 (Selskoe khozyajstvo Krasnodarskogo kraya: statisticheskiy sbornik 2013, 2014).

However, it should be noted that this positive dynamics is only caused by the increasing gross collections of plant products (table 3).

Table 3 - The agricultural production in farms of all categories of the Krasnodar Krai, mil. Rub

\begin{tabular}{|l|c|c|c|c|c|c|}
\hline Indicator & 2009 & 2010 & 2011 & 2012 & 2013 & from 2013 to 2009, \% \\
Total & 175198 & 201554 & 239235 & 234524 & 254710 & 145,4 \\
including & 107713 & 128886 & 159203 & 158550 & 184477 & 171,3 \\
Plant products & 67485 & 72668 & 80032 & 75974 & 70233 & 104,1 \\
Animal products & 6745 & \\
\hline
\end{tabular}

The production of animal products has increased by $4,1 \%$, whereas plant ones - by $71,3 \%$ (Selskoe khozyajstvo Krasnodarskogo kraya: statisticheskiy sbornik 2013, 2014).

The cultivated crops area in farms of all categories of the Krasnodar Krai during the studied period remained stable showing separate changes in the structure (table 4).

Table 4 - The cultivated crops area in farms of all categories of the Krasnodar Krai, thous. Ha

\begin{tabular}{|l|c|c|c|c|c|c|}
\hline Indicator & 2009 & 2010 & 2011 & 2012 & 2013. & from 2013 to 2009, \% \\
The cultivated area, total & 3657,5 & 3634,4 & 3621 & 3600,2 & 3657 & 99,9 \\
Cereal and pulse crops & 2195,8 & 2155,4 & 2177,1 & 2165,7 & 2390 & 109,1 \\
including & 1297,3 & 1309,8 & 1306,7 & 1127,7 & 1387 & 106,9 \\
Winter wheat & 230,3 & 189,3 & 155,3 & 91,6 & 142 & 61,7 \\
Winter barley & 5,3 & 6,2 & 4,6 & 10,3 & 5 & 100,0 \\
Spring wheat & 425,5 & 412,5 & 470,4 & 656,7 & 621 & 145,8 \\
\hline Grain maize & &
\end{tabular}




\begin{tabular}{|l|c|c|c|c|c|c|}
\hline Barley & 65,3 & 52,6 & 51,3 & 81,8 & 58 & 89,2 \\
Buckwheat & 0,2 & 0,2 & 0,2 & 0,7 & 0,3 & 150,0 \\
Rice & 120,6 & 133,4 & 135 & 133,3 & 128 & 105,8 \\
Pulses & 28,8 & 31,3 & 34,3 & 37,7 & 29 & 100,0 \\
Industrial crops & 809,1 & 873,3 & 840,4 & 877,1 & 785 & 97,0 \\
Potatoes and vegetable gourds & 132,3 & 137,7 & 140,2 & 140 & 129 & 97,7 \\
Feed crop & 520,3 & 468 & 463,3 & 417,4 & 353 & 67,9 \\
\hline
\end{tabular}

From 2009 to 2013 the production of cereal and pulse crops, sugar beet, fruits, grape berries, less sunflower, potatoes, and vegetables has increased. The production of feeding root crops, corn for silage and green feed has fallen (table 5).

In the plant industry some agricultural producers make the production on extensive and outdated technologies using seeds with the low level of genetic potential. At the same time the farms using effective technologies of the intensive resource-saving type are absolutely influenced by the foreign grades of seeds of green crops, sugar beet and corn.

The agrarian sector of the edge faces a serious problem concerning unused irrigated lands, and also deterioration and unsatisfactory technical condition of the fixed meliorative assets.

Table 5 - The gross collections in farms of all categories of the Krasnodar Krai, thous. Tons

\begin{tabular}{|l|c|c|c|c|c|c|}
\hline Indicator & 2009 & 2010 & 2011 & 2012 & 2013 & from 2013 to 2009, \% \\
Cereal and pulse crops (after completion) & 9486 & 9943 & 11455 & 8839 & 12038 & 126,9 \\
among them & 5928 & 6516 & 7203 & 4493 & 6954 & 117,3 \\
Winter wheat & 1080 & 931 & 836 & 340 & 752 & 69,6 \\
Winter barley & 727 & 828 & 824 & 857 & 727 & 100,0 \\
Rice & 1440 & 1395 & 2246 & 2753 & 3293 & 228,7 \\
Grain maize & 66 & 74 & 96 & 82 & 60 & 90,9 \\
Pulse crops & 4461 & 7095 & 9283 & 8179 & 67 & 1,5 \\
Sugar beet (factorial) & 1149 & 1029 & 1056 & 1100 & 1167 & 101,6 \\
Sunflower & 534 & 525 & 578 & 582 & 562 & 105,2 \\
Potatoes & 672 & 668 & 760 & 754 & 716 & 106,5 \\
Vegetables & 42 & 35 & 43 & 30 & 32 & 76,2 \\
Feeding root crops & 2842 & 2003 & 2561 & 2022 & 2062 & 72,6 \\
Corn for silage and green feed & 248 & 213 & 270 & 312 & 389 & 156,9 \\
Fetuses and berries & 137 & 132 & 202 & 148 & 211 & 154,0 \\
Grape & \multicolumn{7}{|r|}{} \\
\hline
\end{tabular}

In the structure of the agriculture gross output of the Krasnodar Krai the share of animal products is steadily falling.

So, if in 2010 the share of animal products in farms of all categories is $36,1 \%$, in $2013-27,6 \%$ (Selskoe khozyajstvo Krasnodarskogo kraya: statisticheskiy sbornik 2013, 2014).

The results of the animal industry activity of the Krasnodar Krai in 2013 show that a situation in the branch within the main directions is difficult. There is a tendency of the reduction of the number of large cattle, pigs, horses. So, the number of large cattle from 2009 to 2013 has fallen by $15 \%$, of pigs - by $73,3 \%$. The alternative types of the animal industry, especially actual for the small business patterns increase the cattle stock by insufficiently high rates (table 6).

The production indicators almost of all types of the animal production (milk, meat of large cattle and pigs, eggs, wool, honey) have decreased during the period from 2009 to 2013. An exception is the poultry meat production where within 5 there were the high production growth rates- $76,4 \%$. There is the increase of production of the lamb meat and the goat meat by $18,2 \%$ (Selskoe khozyajstvo Krasnodarskogo kraya: statisticheskiy sbornik 2013, 2014).

Table 6 - Cattle stock on categories of farms of the Krasnodar Krai, thous. Heads

\begin{tabular}{c|c|c|c|c|c|c|c|}
\hline Year & Large cattle & Including Cows & Pigs & Sheep and goats & Horses & Bird & Rabbits \\
1 & 2 & 3 & 4 & 5 & 6 & 7 & 8 \\
2009 & 672 & 265 & 1081 & 153 & 14 & 21000 & 147,3 \\
2010 & 649 & 259 & 1001 & 152 & 14 & 22000 & 146,5 \\
2011 & 634 & 255 & 835 & 154 & 14 & 24000 & 150,9 \\
2012 & 592 & 241 & 311 & 156 & 13 & 26000 & 172,3 \\
\hline
\end{tabular}




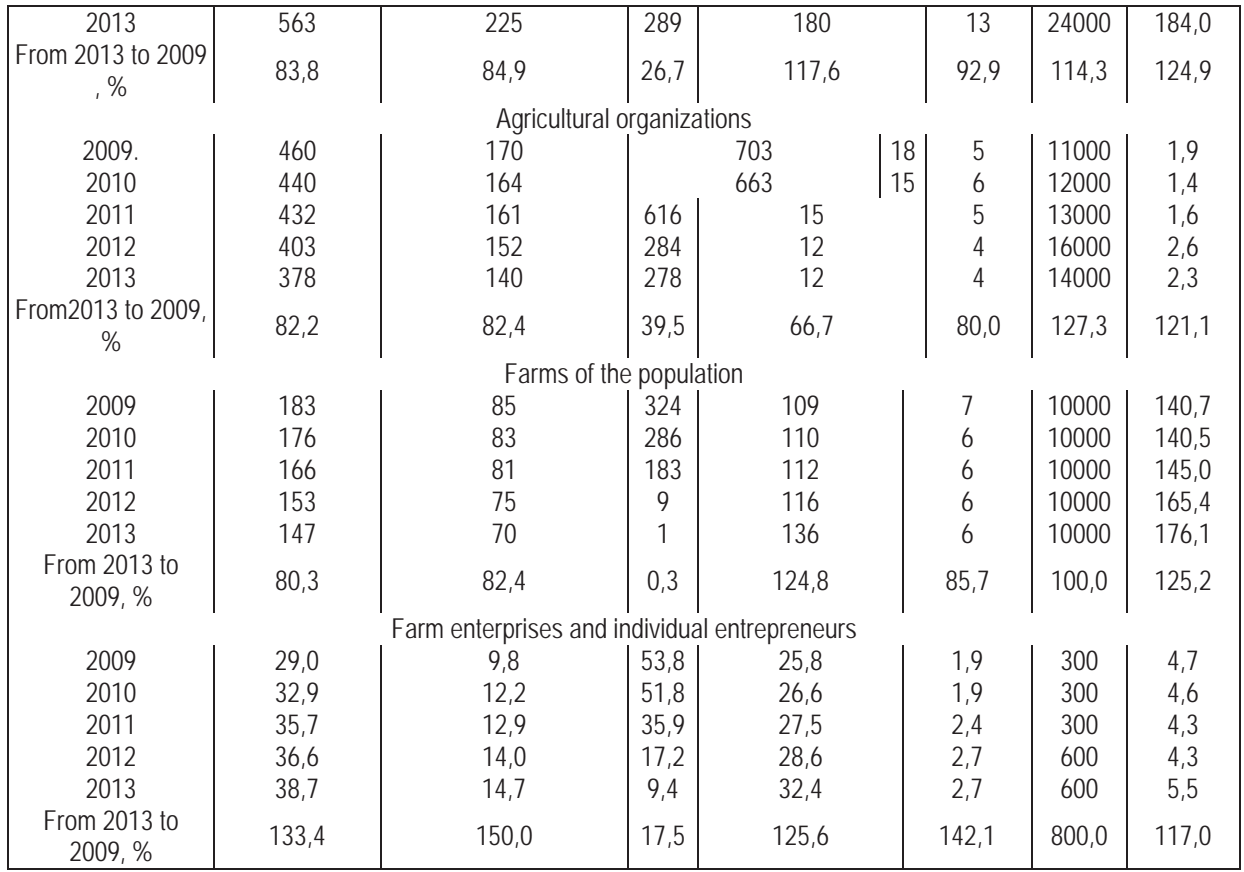

Table 7 shows the animal industry production in the section of separate farms categories of the Krasnodar Krai during the period from 2009 to 2013.

The branch of the animal industry shows the negative dynamics where the main problems are the low development level of beef and dairy cattle breeding and the decline of the pig breeding subsector.

Table 7 - The production of the main livestock products on categories of farms of the Krasnodar Krai

\begin{tabular}{|c|c|c|c|c|c|c|}
\hline Indicator & 2009 & 2010 & 2011 & 2012 & 2013 & From 2013 to $2009, \%$ \\
\hline \multicolumn{7}{|l|}{ Farms of all categories } \\
\hline Cattle and bird for slaughter (in live weight), thousand tons & 519,0 & 542,6 & 585,0 & 564,1 & 465,2 & 89,6 \\
\hline $\begin{array}{l}\text { Cattle and bird for slaughter for slaughter (in slaughter weight), } \\
\text { thousand tons }\end{array}$ & 375,5 & 394,0 & 428,6 & 411,8 & 336,3 & 89,6 \\
\hline $\begin{array}{l}\text { including } \\
\text { Beef and veal }\end{array}$ & 68,4 & 68,4 & 65,1 & 68,4 & 68,3 & 99,9 \\
\hline Pork & 178,2 & 180,6 & 185,1 & 139,8 & 42,2 & 23,7 \\
\hline Lamb and goat meat & 1,1 & 1,1 & 1,2 & 1,3 & 1,3 & 118,2 \\
\hline Fowl & 126,3 & 142,4 & 175,6 & 200,7 & 222,8 & 176,4 \\
\hline Milk, thous. $\mathrm{t}$ & 1426,1 & 1396,7 & 1376,6 & 1389,2 & 1319,4 & 92,5 \\
\hline Eggs, mil. things & 1735,7 & 1802,0 & 1681,2 & 1679,1 & 1484,6 & 85,5 \\
\hline Wool, $\mathrm{t}$ & 294 & 298 & 262 & 258 & 251 & 85,4 \\
\hline Honey, t & 3059 & 2853 & 2586 & 2508 & 2353 & 76,9 \\
\hline \multicolumn{7}{|l|}{ Agricultural organizations } \\
\hline Cattle and bird for slaughter (in live weight), thousand tons & 244,1 & 269,5 & 304,8 & 317,8 & 312,0 & 127,8 \\
\hline $\begin{array}{l}\text { Cattle and bird for slaughter for slaughter (in slaughter weight), } \\
\text { thousand tons }\end{array}$ & 175,7 & 195,6 & 224,9 & 235,0 & 231,4 & 131,7 \\
\hline Milk, thous. t & 904,9 & 869,6 & 851,2 & 874,2 & 824,7 & 91,1 \\
\hline Eggs, mil. things & 1007,8 & 1069,6 & 947,9 & 945,2 & 764,5 & 75,9 \\
\hline Wool, t & 35 & 40 & 30 & 26 & 25 & 71,4 \\
\hline Honey, t & 245 & 117 & 104 & 93 & 85 & 34,7 \\
\hline
\end{tabular}




\begin{tabular}{|l|c|c|c|c|c|c|}
\hline Cattle and bird for slaughter (in live weight), thousand tons & 8,6 & 8,9 & 9,7 & 9,4 & 7,6 & 88,4 \\
\hline $\begin{array}{l}\text { Cattle and bird for slaughter for slaughter (in slaughter weight), } \\
\text { thousand tons }\end{array}$ & 6,3 & 6,5 & 7,0 & 6,8 & 5,4 & 85,7 \\
\hline Milk, thous. t & 51,7 & 60,0 & 68,5 & 74,0 & 80,5 & 155,7 \\
\hline Eggs, mil. things & 17,6 & 18,1 & 18,3 & 18,3 & 18,1 & 102,8 \\
\hline Wool, t & 66 & 63 & 55 & 56 & 53 & 80,3 \\
\hline Honey, t & 54 & 65 & 64 & 63 & 59 & 109,3 \\
\hline Farms of the population & 266,3 & 264,2 & 270,5 & 236,9 & 145,6 & 54,7 \\
\hline Cattle and bird for slaughter (in live weight), thousand tons & 193,5 & 191,9 & 196,7 & 170,0 & 99,5 & 51,4 \\
\hline $\begin{array}{l}\text { Cattle and bird for slaughter for slaughter (in slaughter weight), } \\
\text { thousand tons }\end{array}$ & 469,5 & 467,1 & 456,9 & 441,0 & 414,1 & 88,2 \\
\hline Milk, thous. t & 710,3 & 714,3 & 715,0 & 715,6 & 702 & 98,8 \\
\hline Eggs, mil. things & 193 & 195 & 177 & 176 & 173 & 89,6 \\
\hline Wool, t & 2760 & 2671 & 2418 & 2352 & 2209 & 80,0 \\
\hline Honey, t & 7 \\
\hline
\end{tabular}

In the branch of the animal industry of the Krasnodar Krai animals have the weak genetic potential (thus in the pig breeding subsector all breeding farms are liquidated) and poor meat qualities that, in turn, causes a sharp dependence of the meat-processing organizations on import raw materials.

\subsection{The financial results of the agricultural organizations activity of the Krasnodar Krai}

The results of the agricultural organizations activity mostly define the financial results of the agro-industrial complex.

So, the production profitability in the agricultural organizations of the Krasnodar Krai according to the results of 2013 is 18,9\%, at the general share of the unprofitable farms $21 \%$. The profitability of the branch of the plant industry was at the level of $22,3 \%$, and the animal industry - 8,5\% (table 8) (Selskoe khozyajstvo Krasnodarskogo kraya: statisticheskiy sbornik 2013, 2014).

Table 8 - The financial results of the agricultural organizations activity of the Krasnodar Krai (without the subjects of a small business)

\begin{tabular}{|l|c|c|c|c|c|c|}
\hline Indicator & 2009 & 2010 & 2011. & 2012 & 2013 & From 2013 to 2009, \% \\
Number of the agricultural organizations & 355 & 350 & 336 & 324 & 312 & 87,9 \\
among them & 56 & 68 & 65 & 72 & 65 & 116,1 \\
Unprofitable, units & 16 & 19 & 19 & 22 & 21 & - \\
\% & 74381 & 92385 & 101162 & 106857 & 109792 & 147,6 \\
Monetary revenue, total, million rub. & 57153 & 65197 & 80663 & 68464 & 72190 & 126,3 \\
including & 16716 & 14734 & 18747 & 21313 & 16504 & 98,7 \\
Plant industry & 11750 & 18009 & 17455 & 16376 & 17435 & 148,4 \\
Animal industry & 9540 & 13716 & 15849 & 12271 & 13148 & 137,8 \\
Profit on sales, everything, one million rub. & 2021 & 1811 & 1579 & 1521 & 1300 & 64,3 \\
including & 18,8 & 24,2 & 20,9 & 18,1 & 18,9 & - \\
Plant industry & 20,0 & 26,6 & 24,5 & 21,8 & 22,3 & - \\
Animal industry & 13,8 & 14,0 & 9,2 & 7,7 & 8,5 & - \\
Profitability, \% & 57909 & 73673 & 83221 & 123344 & 101164 & 174,7 \\
including & 19195 & 22097 & 27917 & 28605 & 28854 & 150,3 \\
Plant industry & 17748 & 23461 & 27048 & 28696 & 28574 & 161,0 \\
Animal industry & \multicolumn{7}{|l}{} \\
Loans and credits, one million rub & Loans payable, million rub. & & & & \\
Receivables, million rub. & &
\end{tabular}

At the general reduction of the agricultural organizations by 43 units, the number of the unprofitable organizations has increased from 56 to 65 organizations.

Loans and credits of the agricultural organizations have increased to 101164 mil. rub. in 2013 against 57909 mil. rub. in 2009 that is $74,7 \%$. The loan payable during the studied period has increased by 50,3\% (Selskoe khozyajstvo Krasnodarskogo kraya: statisticheskiy sbornik 2013, 2014). 
The reached profitability level does not provide the expanded reprocessing in the agricultural organizations of the Krasnodar Krai (Zhukov, Basenko, Romanov, Babayan \& Fomichenko, 2015).

The agriculture is the main supplier of raw materials for the processing and industrial AIC organizations of the Krasnodar Krai.

It should be noted that during 2009-2013 the number of the operating organizations in the sphere of the agricultural production processing has fallen (table 9).

Table 9 - The number of the operating organizations in production of AIC foodstuff of the Krasnodar Krai

\begin{tabular}{|l|c|c|c|c|c|c|}
\hline Indicator & 2009 & 2010 & 2011 & 2012 & 2013 & From 2013 to 2009, \% \\
Number of the operating organizations, units & 2236 & 2282 & 2157 & 2087 & 2078 & 92,9 \\
including & 1178 & 1290 & 1253 & 1152 & 1110 & 94,2 \\
Without subjects of a small business & 1058 & 992 & 904 & 935 & 968 & 91,5 \\
Small organizations & & \\
\hline
\end{tabular}

From 2009 to 2013 the number of the operating organizations has fallen from 2236 to 2078, that is by 158 units, 68 of them are the large and medium organizations, 90 are small ones (Selskoe khozyajstvo Krasnodarskogo kraya: statisticheskiy sbornik 2013, 2014). The reduction of the number of the operating organizations has caused the reduction of labor force (table 10).

Table 10 - The number of labor forces in the sphere of foodstuff AIC production of the Krasnodar Krai

\begin{tabular}{|l|c|c|c|c|c|c|}
\hline Indicator & 2009 & 2010 & 2011 & 2012 & 2013 & From 2013 to 2009, \% \\
Average number of labor forces, thousand people & 82,6 & 79,4 & 76,4 & 73,3 & 70,2 & 85,0 \\
including & 63,8 & 60,9 & 58,5 & 55,4 & 52,3 & 82,0 \\
\hline Without entities of a small business & & \\
\hline
\end{tabular}

The average number of labor forces in the sphere of processing has fallen by 12,4 thousand people, including in entities of small business by 11,5 thousand people (Selskoe khozyajstvo Krasnodarskogo kraya: statisticheskiy sbornik 2013, 2014).

The release of this number of people in the production sphere of food products sets for regional public authorities and bodies of the municipal management a task of their employment as strategically important within the rural territories development, demanding the further improvement of forms and mechanisms of the state support. There is often a tendency of the decrease in costs on a unit of the processed production, nevertheless the branch production profitability of foodstuff in AIC of the Krasnodar Krai has slightly decreased: from 9,7\% in 2009 to 9,6\% in 2013 (table 11) (Selskoe khozyajstvo Krasnodarskogo kraya: statisticheskiy sbornik 2013, 2014).

Table 11 - The financial results of foodstuff production in AIC of the Krasnodar Krai (without entities of a small business)

\begin{tabular}{|l|c|c|c|c|c|c|}
\hline Indicator & 2009 & 2010 & 2011 & 2012 & 2013 & From 2013 to 2009, \% \\
Balanced financial result (profit minus loss), thousand rub. & 3219,9 & 5981,3 & 2752,8 & 8589,7 & 8324,1 & 258,5 \\
Level of production profitability, \% & 9,7 & 9,1 & 7,8 & 10,2 & 9,6 & - \\
Costs on 1 ruble of production (works, services), penny & 89,8 & 88,8 & 86,8 & 86,7 & 82,6 & 92,0 \\
\hline
\end{tabular}

The lack of sales infrastructure for many agricultural producers is a serious limiter in the activity. This problem is connected with the absence of the marketing structures operating in the producers' interests.

The undeveloped infrastructure of the primary processing of production, and also the infrastructure of storage and transportation have also negative influence on the agricultural producers' activity.

Of course, social problems of the agrarian sector also demand the coordination and protection of farm people interests (Karepova, Karabulatova, Klemovitsky, Novikov, Stratan \& Perova, 2015).

\section{Results and Discussions}

The results of the carried-out analysis show that economic reforms of the last years caused the emergence of negative processes in all branches of AIC of the Krasnodar Krai despite the measures of the state support. 
Since 2005 in the territory of the Russian Federation there was accepted to realization the priority national project "Development of $\mathrm{AIC}$ " including a number of the support programs for agricultural producers, to speed up the work of which is only possible by means of measures concentration of the state influence on such strategic development directions as:

1) Reclamation of land.

The actions providing the meliorative fund development assume the introduction of innovative ways of irrigation, meliorative systems of new generation that will allow save water resources by 25-30\%; restoration of the infrastructure on the existing hydromeliorative systems and its creation at newly built construction objects; information and analytical providing sphere of the melioration.

2) Development of elite seed farming.

The priority directions of development of the plant industry branch of the Krasnodar Krai are: the further development of corn production, the increasing production of soybean and colza, the increasing production of vegetables, the increasing gross output of sugar beet.

Considering that the level of competitiveness of the plant industry is mainly defined by the quality of seeds, actions of the state support have to be directed on the increasing share of the area of the lands sowed by elite seeds, and the improvement of the system's mechanisms of the state crop variety testing, cultures, stimulating the output growth of seeds which are priority for the plant industry of croppers of the edge with the high technological characteristics meeting the requirements of the international standards (Novikov, Klochko, Yarushkina, Zhukov \& Dianova, 2015).

3) Intensive development of the animal industry.

This direction assumes a creation of organizational, economic and legal conditions for the increasing livestock and efficiency of farm animals. The organization of family farms on the basis of farm enterprises, the completion of implementation of the largest investment projects in the branch.

The successful development of the animal industry and the solution of a problem of the increasing outputs and quality of meat production are impossible without a creation of breeding base with the modern organizational structure and the corresponding genetics. In compliance with what renewal of measures for the organization of the selection and genetic centers is necessary.

4) Support of the small forms of management.

Stimulation to the development of small agricultural producers assumes a creation of conditions for the sale infrastructure development, primary processing, storage and transportation of production made by them; introductions of the intensive technologies; access to the financial resources (Kobersy, et al., 2015).

However, the entry of the Russian Federation in the ranks of the World Trade Organization (WTO) predetermines the exclusive use of the state support measures which are indirectly influencing production which mainly promotes the institutional transformations and does not consider a direct receiving of the financial means or privileges from the state (Sidorenko, 2008).

It should be noted that the sharp political situation in the international space predetermines the prospects of protectionist influence from regional authorities concerning the large distribution networks, and also the distributive companies concerning the sale of the agricultural production.

Support of authorities in the form of a formation of the logistic basis of the agro-industrial complex by means of production, processings and storages of the agricultural production on the cooperative beginnings and ensuring the regular delivery in the distribution centers and distribution networks of food that is ready to be used, can have an essential impact.

According to the WTO the state support measures for the rural consumer cooperation development refer to "a green basket" because they do not make a direct distorting impact on the trade (Sidorenko, 2008).

Independent on volumes, but necessary for the sustainable development of the agro-industrial complex, the state support cooperation measures in the village can significantly change the structure of the agricultural production in favor of entities of small business, raise the income of farm people and promote the agrarian and industrial complex development of the Krasnodar Krai.

For example, the system of the contractual relations concerning production, processing and sales of the pig breeding products between the agricultural organizations and farm enterprises can be the organizational form of the entities relationships regulation.

The basis for this interaction is production of pork by means of cooperation of the multiplying farm entering into the structure of the selection and genetic center with the small farms which are formed within farm enterprises and farms of the population, specializing only on pig feeding, and also a station of artificial insemination and a feed factory.

The economic feasibility of cooperation of the mentioned producers is confirmed by the fact that the most 
knowledge-intensive stage in the course of reproduction is more effectively carried out on a large sow farm where there is necessary equipment and the personnel of the corresponding qualification (Nesterenko, 2011).

Transition to the final links of a technological chain allows the small forms of management to avoid the expenses and risks connected with the labor-consuming stages of the reproduction process, not to carry out the considerable capital investments for formation of a breeding stock, and to increase the further sales by the agricultural organizations.

The use of own lines of slaughter has an essential impact on the activity efficiency of the animal industry organizations. However, a construction of high-producing factory demands the considerable investments, and also assumes the transportation of animals that also causes the additional expenses. The use of mobile mini-slaughtering equipment is capable to compensate the lack of the professional equipment of the primary processing to small farms.

The provision to farmers by public authorities or local government with the mobile factory on slaughter and the help in organization of the marketing systems will satisfy the needs of the considered system of cooperation for the primary processing of own production and also its realization (Nesterenko, 2011).

\section{Conclusion}

The processes in the subsector of beef cattle breeding, and also in the plant breeding can be organized the same way.

Creation of conditions for providing and expansion of the financial and credit and material resources availability, guarantees of sale and the demand for made production, stimulations of the economic activity of farm people promoting the employment growth and the increasing income has to be the purpose of the state support in cooperation area.

Thus, a concentration of state regulation on the indirect support measures of strategic development directions is capable to provide a stimulation of "independent mechanisms" of the internal potential of the agro-industrial complex of the Krasnodar Krai.

\section{References}

Nesterenko, M.A. (2011). Sovershenstvovanie organizatsionno-ekonomicheskogo mehanizma razvitiya svinovodstva (po materialam krasnodarskogo kraya) (Dissertatsiya na soiskanie uchenoi stepeni kandidata ekonomicheskih nauk). Kubanskiy gosudarstvennyi agrarnyi universitet, Krasnodar, Rossijskaya Federatsiya.

Selskoe khozyajstvo Krasnodarskogo kraya: statisticheskiy sbornik (2013). Territorialnyi organ Federalnoi sluzhby gosudarstvennoi statistiki po Krasnodarskomu krayu, Krasnodar, Rossijskaya Federatsiya.

Selskoe khozyajstvo Krasnodarskogo kraya: statisticheskiy sbornik (2014). Territorialnyi organ Federalnoi sluzhby gosudarstvennoi statistiki po Krasnodarskomu krayu, Krasnodar, Rossijskaya Federatsiya.

Sidorenko, V.V. (2008). Gosudarstvennoe regulirovanie rynochnoi ekonomiki: uchebnoe posobie dlya vuzov. Krasnodar: Mir Kubani.

Novikov, V.S., Klochko, E.N., Yarushkina, E.A., Zhukov, B.M., Dianova, V.A. (2015) On peculiarities of the virtual economy of modern Russia: categories, virtual relationships, educational constructs. Mediterranean Journal of Social Sciences, 363 (247-257).

Karepova, S.G., Karabulatova, I.S., Klemovitsky, S.V., Novikov, V.S., Stratan, D.I., Perova, A.E. (2015) New approaches to the development of methodology of strategic community planning. Mediterranean Journal of Social Sciences, 363 (357-363).

Kobersy, I., Barmuta, K., Muradova, S., Dubrova, L., \& Shkurkin, D. (2015). The System of the Methodological Principles of Management of Enterprise Development. Mediterranean Journal Of Social Sciences, 6(3 S4), 25. Retrieved from http://www.mcser.org/journal/ index.php/mjss/article/view/6707

Zhukov, B.M., Basenko, V.P., Romanov, A.A., Babayan, Y.V., Fomichenko, N.G. (2015) The intellectual and educational resources as an institutional factor of innovative economy formation. Mediterranean Journal of Social Sciences, 363 (283-295). 